\title{
Kedudukan Fikih, Ushul Fiqh dan al-Qawaid al-Fiqhiyyah dalam Sistem Ekonomi Syari'ah
}

\author{
Muhammad Zaki ${ }^{1}$ \\ Institut Agama Islam (IAI) Yasni Bungo \\ mdzakiismail@gmail.com
}

\begin{abstract}
Fikih is a regulation for implementing sharia law and is closely related to the study of Islamic law. This rule in understanding and formulating sharia law is called usul fiqh. Meanwhile, alqawaid al-fiqhiyyah is a general set of fikih rules covering all branches of fiqh issues that serve as guidelines for determining the law of every fikih issue, whether it has been appointed by the texts or for which there is no text at all. This paper is a literature review that aims to briefly explain the meaning of fikih, ushul fiqh, and al-qawaid al-fiqhiyyah, as well as the process of being formed, the scope of the discussion and the object of each study. Fikih, ushul fiqh and alqawaid al-fiqhiyyah will not be separated from sharia economic activities, especially in facing economic developments in general as it is today. In fact, they are the basis for sharia economic activities to occur in order to run according to the will of Allah Swt.
\end{abstract}

Keywords: Fikih, Ushul fiqh, al-Qawaid al-fiqhiyyah, Sharia economic

\begin{abstract}
Abstrak
Fikih merupakan peraturan pelaksanaan hukum syara' dan sangat berkaitan erat dengan kajian syariat Islam. Kaidah dalam memahami dan merumuskan hukum syara' ini disebut dengan ushul fiqh. Sedangkan al-qawaid al-fiqhiyyah adalah himpunan kaedah-kaedah fikih yang umum yang meliputi seluruh cabang masalah-masalah fikih yang menjadi pedoman untuk menetapkan hukum setiap masalah-masalah fikih baik yang telah ditunjuk oleh nash maupun yang sama sekali belum ada nashnya. Makalah ini merupakan kajian literatur yang bertujuan untuk menjelaskan secara ringkas tentang pengertian fikih, ushul fiqh, dan al-qawaid al-fiqhiyyah, serta proses terbentuk, ruang lingkup pembahasan dan objek kajiannya masing-masing. Fikih, ushul fiqh, dan al-qawaid al-fiqhiyyah tidak akan bisa dipisahkan dari aktivitas ekonomi syariah, terutama dalam menghadapi perkembangan ekonomi secara umum seperti saat ini. Bahkan ketiga disiplin ilmu tersebut merupakan landasan bagi terjadi aktivitas ekonomi syari'ah agar berjalan sesuai kehendak Allah Swt.
\end{abstract}

Kata Kunci: Fikih, Usul fiqh, al-Qawaid al-fiqhiyyah, Ekonomi syariah

\section{A. Pendahuluan}

Kehendak Allah Swt dapat ditemukan dalam kumpulan wahyu-Nya yang disebut Alquran dan penjelasan yang diberikan oleh Nabi Muhammad Saw dalam hadis atau sunnah. Segala sesuatu yang dikehendaki oleh Allah Swt berkenaan dengan tindak perbuatan manusia disebut hukum syara' yang merupakan pedoman pokok dalam berbentuk petunjuk umum dan terdiri dari garis-garis besar, serta menurut apa adanya, sehingga belum dapat dilaksanakan secara amaliah. Petunjuk Allah Swt perlu

\footnotetext{
${ }^{1}$ Dosen Fakultas Ekonomi dan Bisnis Islam (FEBI) Institut Agama Islam (IAI) Yasni Bungo
} 
dijabarkan dalam bentuk petunjuk operasional secara rinci dan mudah untuk diamalkan yang disebut fikih dan sangat berkaitan erat dengan kajian syariat Islam.

Perumusan hukum syara' yang bersumber dari Alquran dan hadits diperlukan kaedah khusus, agar terjaga dari kesalahan dan penyimpangan yang disebut dengan ushul fiqh. Perumusan hukum syara ' selain memerlukan kaedah khusus (ushul fiqh), juga selalu berlandaskan kepada dasar-dasar pembuatan syariat yang umum, yakni tidak memberatkan, tidak memperbanyak beban, berangsur-angsur dalam menetapkan hukum dan sejalan dengan kebaikan orang banyak. Jika dikaitkan dengan kaedah-kaedah ushuliyah yang merupakan pedoman dalam menggali hukum syara', maka al-qawaid al-fiqhiyyah merupakan kelanjutannya sebagai petunjuk operasional dalam pengambilan kesimpulan hukum dalam syariat Islam. al-Qawaid al-fiqhiyyah ini, selain berfungsi sebagai tempat bagi para mujtahid mengembalikan seluruh seluk beluk masalah fikih juga sebagai kaedah (dalil) untuk menetapkan masalah-masalah baru yang tidak ditunjuk oleh nash yang jelas (sharih) yang sangat memerlukan untuk ditentukan hukumnya.

Makalah ini merupakan kajian literatur atau pustaka yang bertujuan untuk menjelaskan secara ringkas tentang pengertian fikih, ushul fiqh, dan al-qawaid alfiqhiyyah, serta proses terbentuk, ruang lingkup pembahasan dan objek kajiannya masing-masing. Pada akhir pembahasan, penulis mendudukkan ketiga poin pokok tersebut dalam kaitannya terhadap sistem ekonomi syariah yang sedang berkembang pada saat ini.

\section{B. Pembahasan}

\section{Fikih}

\section{a. Pengertian Fikih Secara Bahasa dan Istilah}

Menurut bahasa (etimologi), kata fikih berasal dari bahasa Arab الفَهُمُ yang berarti paham, seperti pernyataan فَتَّهْتُ الدَّرْنَ yang berarti saya memahami pelajaran itu. ${ }^{2}$ Arti ini sesuai dengan arti fikih dalam salah satu hadis yang diriwayatkan oleh Imam al-Bukhori berikut ini:

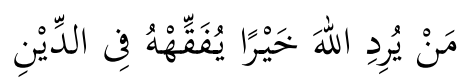

\footnotetext{
${ }^{2}$ Rachmat Syafe'i, Fikih Mu'amalat, (Bandung: Pustaka Setia, 2004), hal. 13.
} 
Artinya: "Barang siapa yang dikehendaki Allah Swt. menjadi orang yang baik di sisi-Nya, niscaya diberikan kepadanya pemahaman yang mendalam dalam pengetahuan agama".3

Menurut terminologi, fikih pada mulanya berarti pengetahuan keagamaan yang mencakup seluruh ajaran agama, baik berupa akidah, akhlak, maupun amaliah (ibadah), yakni sama dengan arti syariah islamiyyah. Namun, pada perkembangan selanjutnya, fikih diartikan sebagai bagian dari syariah islamiyyah, yaitu pengetahuan tentang hukum syariah islamiyyah yang berkaitan dengan perbuatan manusia yang telah dewasa dan berakal sehat yang diambil dari dalil-dalil yang terinci. ${ }^{4}$

Fikih menurut al-Mausu'ah al-Fiqhiyyah secara bahasa adalah pemahaman yang mutlak, baik secara jelas maupun secara tersembunyi. Sebagian ulama berpendapat, bahwa fikih secara bahasa berarti memahami sesuatu secara mendalam. ${ }^{5}$ Para ushuliyyun membagi makna fikih secara istilah dalam tiga fase. Pertama, bahwa fikih sama dengan syariat, yakni segala pengetahuan yang terkait dengan apa-apa yang datang dari Allah Swt, baik berupa akidah, akhlak, maupun perbuatan anggota badan. Kedua, fikih didefinisikan sebagai ilmu tentang hukum-hukum syar'iyyah yang bersandarkan pada dalil-dalil yang terperinci. Ketiga, dan ini yang berlaku hingga saat ini, yaitu ilmu tentang hukum-hukum syariah bersifat furu'iyyah amaliah yang bersandar pada dalil-dalil terperinci. ${ }^{6}$

Dalam pandangan Wahbah az-Zuhaili, terdapat beberapa pendapat tentang definisi kata al-fiqh. Beliau mengutip pendapat Abu Hanifah yang mendefinisikannya

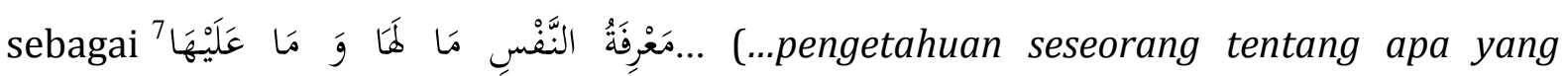
menguntungkan dan apa yang merugikan). Selain itu Wahbah az-Zuhaili juga mengutip

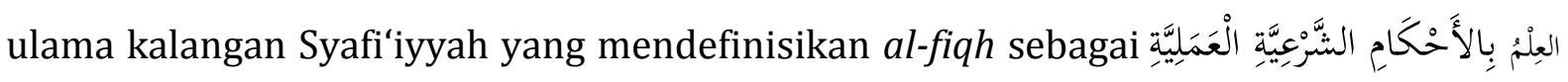

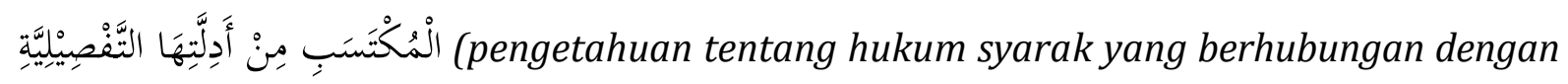
amal perbuatan, yang digali dari dalil yang terperinci).

\footnotetext{
${ }^{3}$ Ibid.

${ }^{4}$ Ibid., hal. 13-14.

${ }^{5}$ Wuzarah al-Awqaf wa asy-Syu'un al-Islamiyyah, al-Mausu'ah al-Fiqhiyyah, (Kuwait: Wuzarah alAwqaf wa asy-Syu'un al-Islamiyyah, Cet. 2, 1983 M/1404 H), hal. 11.

${ }^{6}$ Ibid, hal. 21-22.

${ }^{7}$ Satria Effendi dan M. Zaeni, Usul Fikih, (Jakarta: Prenada Media, 2005), hal. 2.
} 
Sedangkan al-Amidi memberikan definisi fikih yang berbeda dengan definisi di atas, yaitu: "ilmu tentang seperangkat hukum-hukum syara' yang bersifat furu'iyyah yang berhasil didapatkan melalui penalaran atau istidlal". ${ }^{8}$ Hakekat fikih menurut Amir Syarifuddin dalam bukunya Garis-Garis Besar Fikih adalah: 1) Ilmu tentang hukum Allah Swt, 2) Membicarakan hal-hal yang bersifat amaliyah furu'iyyah, 3) Pengertian tentang hukum Allah Swt didasarkan pada dalil terperinci, dan 4) Digali dan ditemukan melalui penalaran dan istidlal seorang mujtahid atau ahli fikih (faqih). ${ }^{9}$

Berdasarkan beberapa pengertian yang telah dikemukakan di atas penulis menyimpulkan bahwa fikih merupakan seperangkat aturan hukum atau tata aturan yang menyangkut kegiatan dalam kehidupan manusia dalam berinteraksi, bertingkah laku dan bersikap yang bersifat lahiriah dan amaliah, yang merupakan hasil penalaran dan pemahaman yang mendalam terhadap syariah oleh para mujtahid berdasarkan pada dalil-dalil yang terperinci. Dengan kata lain bahwa fikih terbatas pada hukumhukum yang bersifat aplikatif dan furu'iy (cabang) dan tidak membahas perkaraperkara i'tiqady (keyakinan) walaupun pada awal kemunculannya merupakan bagian yang tidak terpisah. Fikih adalah hukum Islam yang tingkat kekuatannya hanya sampai praduga (zhan), karena ditarik dari dalil-dalil yang bersifat zhanny. Hukum fikih yang bersifat zhanny mengandung pengertian adanya campur tangan akal pikiran manusia dalam penarikannya dari Alquran dan sunnah Rasulullah Saw. ${ }^{10}$

\section{b. Proses Pembentukan serta Perkembangan Fikih}

Sesungguhnya ilmu fikih telah terbentuk sejak masa Nabi Muhammad Saw dalam bentuk yang sederhana dan mudah dilaksanakan. Amir Syarifuddin membagi fase perkembangan fikih dalam lima fase sebagai berikut:11

1) Fikih pada Masa Nabi Muhammad Saw.

Fikih merupakan hasil penalaran seorang ahli atas maksud hukum Allah Swt yang berhubungan dengan tingkah laku manusia. Nabi Saw memberikan penjelasan mengenai maksud setiap ayat hukum kepada umatnya, sehingga ayat-ayat yang tadinya belum dalam bentuk petunjuk praktis, menjadi jelas dan dapat dilaksanakan secara praktis. Nabi Saw memberikan penjelasan dengan ucapan, perbuatan, dan pengakuannya yang kemudian disebut sunnah Nabi Saw. Penjelasan dari Nabi Saw yang

\footnotetext{
${ }^{8}$ Amir Syarifuddin, Usul Fiqh Jilid 1, (Jakarta: PT. Logos Wacana Ilmu, 1997), hal. 3.

${ }^{9}$ Amir Syarifuddin, Garis-Garis Besar Fiqh, (Jakarta: Prenada Media, 2003), hal. 7.

${ }^{10}$ Totok Jumantoro dan Samsul Munir Amin, Kamus Ilmu Usul Fikih, (Jakarta: Amzah, 2005), hal. 67.

${ }^{11}$ Syarifuddin, Garis, hal. 6-32.
} 
berbentuk sunnah itu merupakan hasil penalaran atas ayat-ayat hukum dan dapat disebut fikih atau lebih tepat disebut 'fikih sunnah'.12 Hal ini telah menunjukkan bahwa pembentukan fikih sudah dimulai sejak masa Nabi Saw yang mencakup bidang yang sangat luas meskipun dalam bentuk pelaksanaan yang sederhana dan mudah.

2) Fikih pada Masa Sahabat

Dengan wafatnya Nabi Muhammad Saw sempurnalah turunnya ayat-ayat Alquran dan sunnah Nabi Saw juga dengan sendirinya sudah terhenti. Kemudian terjadi perubahan yang besar sekali dalam kehidupan masyarakat, karena telah meluasnya wilayah Islam dan semakin kompleksnya kehidupan umat. Terdapat tiga hal pokok yang berkembang pada masa sahabat dalam masalah hukum, yakni: Pertama, banyaknya muncul kejadian baru yang membutuhkan jawaban hukum yang secara lahiriah tidak dapat ditemukan jawabannya dalam Alquran maupun penjelasan dari sunnah Nabi Saw. Kedua, timbulnya masalah-masalah yang secara lahir telah diatur ketentuan hukumnya dalam Alquran maupun sunnah Nabi Saw, namun ketentuan itu dalam ketentuan sulit untuk diterapkan dan menghendaki pemahaman baru agar relevan dengan perkembangan dan persoalan yang dihadapi.

Ketiga, dalam Alquran terdapat penjelasan terhadap suatu kajian secara jelas dan terpisah. Bila hal tersebut berlaku dalam kejadian tertentu, para sahabat menemukan kesulitan dalam menerapkan dalil-dalil yang ada. Ketiga persoalan di atas memerlukan pemikiran mendalam atau nalar dari para ahli yang disebut ijtihad. Dalam menghadapi hal tersebut berkembanglah pemikiran para sahabat dalam merumuskan fikih, sehingga masa ini dapat disebut dengan masa pengembangan fikih.

3) Fikih pada Masa Imam Mujtahid

Sesudah masa sahabat, penetapan fikih dengan menggunakan sunnah dan ijtihad begitu berkembang dan meluas. Dalam kadar penerimaan dua sumber itu terlihat kecenderungan mengarah pada dua bentuk. Pertama, delam menetapkan hasil ijtihad lebih banyak menggunakan hadits Nabi Saw dibandingkan dengan menggunakan ijtihad, meskipun keduanya tetap dijadikan sumber. Kelompok yang menggunakan cara ini disebut dengan ahlul hadits yang banyak tinggal di wilayah Hijaz, khususnya Madinah. ${ }^{13}$ Kedua, dalam menetapkan fikih lebih banyak menggunakan sumber ra'yu atau ijtihad ketimbang hadits, meskipun hadits juga banyak digunakan. Kelompok ini

\footnotetext{
${ }^{12}$ Ibid, hal. 6.

${ }^{13}$ Ibid, hal. 29.
} 
disebut ahlu al-Ra'yi yang banyak tinggal di wilayah 'Irak, khususnya Kufah dan Basrah. ${ }^{14}$

4) Fikih pada Masa Taqlid dan Reformulasi Fikih Islam

Akhir dari masa gemilang ijtihad pada periode imam mujtahid ditandai dengan telah tersusunnya secara rapi dan sistematis kitab-kitab fikih sesuai dengan aliran berpikir mazhab masing-masing. Dari satu sisi, pembukuan fikih ini ada dampak positifnya, yaitu kemudahan bagi ummat Islam dalam beramal, karena semua masalah agama telah dapat ditemukan jawabannya dalam kitab fikih yang ditulis para mujtahid sebelumnya. Tetapi dari sisi lain terdapat dampak negatifnya, yaitu terhentinya daya ijtihad, karena orang tidak merasa perlu lagi berpikir tentang hukum, sebab semuanya sudah tersedia jawabannya. Upaya reaktualisasi hukum yang menghasilkan formulasi fikih yang baru, sehingga dapat menuntun kehidupan keagamaan dan keduniaan ummat Islam sesuai dengan persoalan zamannya, terjadi karena adanya keinginan ummat Islam untuk mengembalikan aturan kehidupannya kepada hukum Allah Swt, akan tetapi kitab-kitab fikih belum seluruhnya memenuhi kehidupan tersebut.

\section{c. Ruang Lingkup dan Objek Kajian Fikih}

Secara garis besar, fikih memuat dua hal pokok yang merupakan ibadah kepada Allah Swt. Pertama, tentang apa yang harus dilakukan oleh seorang hamba Allah Swt dalam hubungannya dengan Allah Swt sang penciptanya, atau disebut dengan ibadah secara langsung ('ibadah mahdah), sehingga sering disebut dengan fikih ibadah. Kedua, tentang apa yang yang harus dilakukan oleh seorang hamba dalam hubungannya dengan sesama manusia dan lingkungannya, atau disebut ibadah tidak langsung ('ibadah ijtima'iyyah), sehingga sering disebut fikih muamalah. ${ }^{15}$

Terkait ibadah, bentuk dan cara pelaksanaannya sepenuhnya dilakukan sesuai dengan petunjuk dan kehendak Allah Swt serta penjelasan yang diberikan oleh Nabi Muhammad Saw. Untuk maksud itu, petunjuk Allah Swt serta penjelasan yang diberikan oleh Nabi Saw telah jelas, rinci, dan sempurna, sehingga tidak boleh ditambah, dikurangi dan/atau dirubah. Sedangkan dalam hal muamalah, petunjuk Allah Swt dan penjelasan Nabi Muhammad Saw hanya bersifat umum dan dalam bentuk garis besar. Sejauh yang tidak dijelaskan oleh Allah Swt dan Nabi Saw dapat dilakukan oleh umat dan berlaku padanya kreasi umat untuk mengatur apa-apa yang dibutuhkan dan dianggap baik oleh

\footnotetext{
${ }^{14}$ Ibid.

${ }^{15}$ Ibid., hal. 12-13.
} 
umat berdasarkan prinsip maslahah. Muamalah dalam artian umum adalah pergaulan atau hubungan antara sesama manusia ini. Oleh karena itu, fikih muamalah terbagi dalam beberapa cabang:

1) Hubungan antara sesama manusia berkaitan dengan harta dan kebutuhannya kepada kepemilikan harta itu. Aturan dalam bentuk ini disebut fikih muamalah dalam artian khusus, seperti jual beli, sewa menyewa, dan lain-lain.

2) Hubungan antara sesama manusia berkaitan dengan penyaluran nafsu syahwat dalam mendapatkan keturunan yang sah yang disebut dengan fikih munakahat.

3) Hubungan antara sesama manusia berkaitan dengan pemilikan harta yang timbul sebagai akobat suatu kematian dalam keluarga yang disebut dengan fikih mawarits.

4) Hubungan antara sesama manusia berkaitan dengan terjadinya kejahatan dan sanksi untuk mencegah terjadinya kejahatan tersebut yang dikenal dengan fikih jinayat.

5) Hubungan antara sesama manusia berkaitan dengan usaha manusia mendapatkan hak dan keadilan di pengadilan yang disebut fikih murafa 'at atau qadha'.

6) Hubungan antara sesama manusia dan antara manusia sebagai kelompok dengan pemimpinnya dalam kehidupan bernegara dan berbangsa yang disebut fikih dusturiyyah.

7) Hubungan antara sesama manusia dalam suatu Negara dengan Negara lain dalam masa damai maupun perang yang disebut fikih dauliyyah. ${ }^{16}$

al-Fikri, dalam kitab al-Mu'amalah Al-Maddiyyah wa al-Adabiyyah, sebagaimana dikutip oleh Rachmat Syafe'i, membagi fikih muamalah menjadi dua bagian:

1) al-Mu'amalah al-Maddiyyah, yaitu muamalah yang mengkaji segi objeknya, yaitu benda. Sebagian ulama berpendapat bahwa muamalah ini bersifat kebendaan, yakni benda halal, haram, dan syubhat untuk dimiliki, diperjualbelikan atau diusahakan, benda yang menimbulkan kemudharatan dan mendatangkan kemaslahatan bagi manusia, dan lain-lain. Ruang lingkup mu'amalah maddiyyah adalah: (a) Jual beli (albai); (b) Gadai (rahn); (c) Jaminan dan tanggungan (kafalah dan dhaman); (d) Pemindahan hutang (hiwalah); (e) Jatuh bangkit (tafjis); (g) Batas bertindak (alhajru); (h) Perseroan atau perkongsian (asy-syirkah); (i) Perseroan harta dan tenaga (al-mudharabah); (j) Sewa menyewa tanah (al-musaqat); (k) Upah; (l) Gugatan (syuf'ah); (m) Sayembara (ji'alah); (n) Pembagian bersama (al-qismah); (o) 
Pemberian (al-hibah); (p) Pembebasan (al-ibra), damai (shulhu); dan (q) Beberapa masalah kontemporer (riba, asuransi, kredit, dan lain-lain).

2) al-Mu'amalah al-adabiyyah, yaitu muamalah yang ditinjau dari segi cara tukar menukar benda, yang sumbernya dari pancaindera manusia, sedangkan unsur-unsur penegaknya adalah hak dan kewajiban, seperti jujur, hasud, iri, dendam, dan lain-lain. Ruang lingkup al-mu'amalah al-adabiyyah adalah ijab dan qabul, saling meridhai, tidak ada keterpaksaan dari salah satu pihak, hak dan kewajiban, kejujuran pedagang, penipuan, pemalsuan, penimbunan dan segala sesuatu yang bersumber dari indera manusia yang ada kaitannya dengan peredaran harta. ${ }^{17}$

\section{Ushul Fiqh}

\section{a. Pengertian Ushul Fiqh Secara Bahasa}

Ushul fiqh berasal dari bahasa Arab yang terdiri dari dua kata, yaitu al-Ushul dan al-Fiqh. al-Ushul adalah jamak dari kata al-ashlu (الأَصْلُ (مَا L يُبِنى عَلَيْهِ غَيْرُهُ (landasan tempat membangun sesuatu). Menurut istilah, seperti dikemukakan Wahbah az-Zahuili, kata al-ashlu (الأَصْلُ mengandung beberapa pengertian, yaitu:

1) Bermakna dalil, seperti dalam contoh:

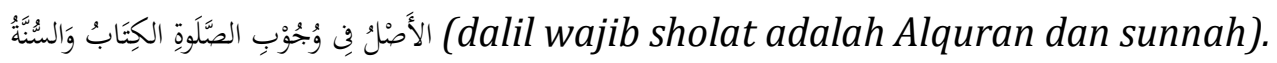

2) Bermakna kaedah umum satu ketentuan yang bersifat umum yang berlaku pada seluruh cakupan, seperti contoh:

"Islam di bangun di atas lima kaedah umum".

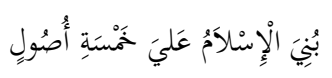

3) Bermakna al-Rajih (yang lebih kuat dari beberapa kemungkinan), seperti contoh:

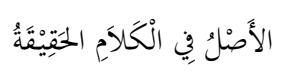

"Pengertian yang lebih kuat dari suatu perkataan adalah pengertian hakikatnya".

4) Bermakna asal, tempat menganalogikan sesuatu yang merupakan salah satu dari rukun qiyas. Misalnya, khamar merupakan asal (tempat mengqiyaskan narkotika).

5) Bermakna sesuatu yang diyakini bilamana terjadi keraguan dalam satu masalah.

Bila kata al-ashlu dihubungkan dengan makna dalil, maka kata ushul al-fiqh berarti dalil-dalil fikih, seperti Alquran, sunnah Rasulullah Saw, ijma', qiyas, dan lainlain. ${ }^{18}$

\footnotetext{
${ }^{17}$ Syafe'i, Fikih, hal. 18.

${ }^{18}$ Effendi, Usul, hal. 2.
} 


\section{b. Pengertian Ushul Fiqh Sebagai Disiplin Ilmu}

Menurut Amir Syarifuddin ushul fiqh adalah ilmu tentang (pemahaman) kaedah kaedah dan pembahasan yang dapat menghantarkan kepada diperolehnya hukumhukum syara' mengenai perbuatan manusia dari dalil-dalilnya yang rinci. Sedangkan ushul fiqh secara istilah teknik hukum adalah ilmu tentang kaedah-kaedah yang membawa kepada usaha merumuskan hukum syara' dari dalilnya yang terperinci, atau dalam arti sederhana adalah kaedah-kaedah yang menjelaskan cara-cara mengeluarkan hukum-hukum dari dalil-dalilnya. Umpamanya dalam kitab-kitab fikih ditemukan ungkapan mengerjakan sholat itu hukumnya wajib, wajibnya melakukan sholat itu disebut hukum syara'. Tidak pernah tersebut dalam Alquran maupun hadits bahwa sholat itu hukumnya wajib, yang tersebut dalam Alquran hanyalah perintah mengerjakan sholat yang berbunyi:

Artinya: Kerjakanlah sholat...

Ayat Alquran yang mengandung perintah mengerjakan sholat itu disebut dalil syara', dan untuk merumuskan kewajiban sholat yang disebutkan oleh hukum syara' tersebut dibutuhkan aturan dalam bentuk kaidah, seperti kaedah: 'setiap perintah itu menunjukkan wajib'. Pengetahuan tentang kaedah-kaedah yang menjelaskan cara-cara mengeluarkan hukum dari dalil-dalil syara tersebut disebut ilmu ushul fiqh. ${ }^{19}$

Dari pemaparan diatas, dapat disimpulkan bahwa ushul fiqh adalah seperangkat pedoman, aturan-aturan atau kaedah-kaedah yang membatasi dan menjelaskan caracara yang harus diikuti oleh seorang mujtahid dalam upayanya menggali dan melahirkan hukum syara' dari dalil yang telah ada, baik dalam Alquran maupun sunnah.

\section{c. Proses Pembentukan dan Perkembangan Ushul Fiqh}

Ushul fiqh lahir pada abad kedua dengan keadaan yang masih bercampur dengan pembahasan ilmu fikih. Dalam pertumbuhannya pada tingkat pertama, ilmu ushul fiqh belum merupakan ilmu yang berdiri sendiri, melainkan terserak-serak dalam kitabkitab fikih yang difungsikan oleh fuqaha' sebagai argumentasi menetapkan hukum fikih serta untuk menerangkan cara-cara mengambil hukum dari dalil-dalil yang dikemukakan.

\footnotetext{
${ }^{19}$ Syarifuddin, Ushul, hal. 34-35.
}

ISTIKHLAF Vol 1 No 1, Maret 2019 
Menurut Ibnu Nadim, orang pertama yang mengumpulkan tulisan ushul fiqh yang masih bercampur dalam kodifikasi fikih Islam menjadi satu perangkat ilmu yang terpisah dan berdiri sendiri adalah Abu Yusuf yang merupakan salah seorang murid Imam Abu Hanifah. Sedangkan yang pertama-tama mengkodifikasi pembahasan dan kaedah-kaedah ilmu ushul fiqh dalam satu kitab yang sangat berharga dan dapat dikaji oleh generasi sekarang adalah al-Imam Muhammad bin Idris asy-Syafi'i (150-2014 H). Karya beliau yang kemudian dituturkan kembali oleh muridnya, ar-Rabi` al-Muradi bernama ar-Risalah. ${ }^{20}$

\section{d. Ruang Lingkup dan Objek Kajian Ushul Fiqh}

Bertitik tolak dari definisi ushul fiqh yang telah dipaparkan di atas, maka bahasan pokok atau objek kajian ushul fiqh adalah tentang:

a. Dalil-dalil atau sumber hukum syara'.

b. Hukum-hukum syara' yang terkandung dalam dalil tersebut.

c. Kaedah-kaedah tentang usaha dan cara mengeluarkan hukum syara' dari dalil atau sumber yang mengandungnya. ${ }^{21}$

Dalam membicarakan sumber hukum dibicarakan pula kemungkinan terjadinya benturan antara dalil-dalil dan cara menyelesaikannya. Dibicarakan pula tentang orangorang yang berhak dan berwenang menggunakan kaedah atau metode dalam melahirkan hukum syara' tersebut, sehingga memunculkan pembahasan tentang ijtihad dan mujtahid. Kajian lain ushul fiqh adalah mengenai tindakan dan usaha yang dapat ditempuh orang-orang yang tidak mempunyai kemampuan dan kemungkinan berijtihad atau pembahasan tentang taqlid dan hal-hal lain yang berhubungan dengannya.

\section{3. al-Qawaid al-Fiqhiyyah}

\section{a. Definisi al-Qawaid al-Fiqhiyyah}

Pengertian kaedah-kaedah fikih (al-qawaid al-fiqhiyyah), dapat diurai dari dua kata yaitu kaedah-kaedah (qawaid) dan fiqh (fikih). Sebagaimana dalam studi ilmu fikih kedua adalah merupakan term yang perlu untuk dijelaskan. Di antara arti kaedah secara bahasa (etimologi) adalah al-asas (dasar), yaitu yang menjadi dasar berdirinya sesuatu. ${ }^{22}$ Dalam kamus Arab-Indonesia al-Munawwir selain al-asas (dasar, asas, dan

\footnotetext{
${ }^{20}$ Mukhtar Yahya dan Fatchur Rahman, Dasar-Dasar Pembinaan Fikih Islam, (Bandung: Al-Ma'arif, 1986), hal. 21-22.

${ }^{21}$ Syarifuddin, Garis, hal. 41-42.

${ }^{22}$ Rachmat Syafe'i, Ilmu Usul Fikih, (Bandung : Pustaka Setia, 2007), hlm. 251.
} 
pondasi) kaedah juga disebut al-qanun (peraturan dan kaidah dasar), al-mabda' (prinsip), dan al-nasaq (metode atau cara). ${ }^{23}$

TM. Hasbi Ash-Shiddieqy sebagaimana dikutip oleh Faturrahman Djamil dalam bukunya Filsafat Hukum Islam menyebutkan bahwa sebagian ahli hukum merumuskan

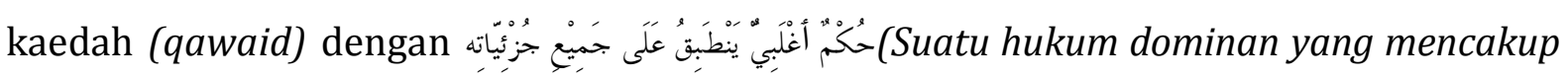
seluruh bagiannya). ${ }^{24}$ Kaedah (qawaid) menurut Ahmad Muhammad asy-Syafi'i adalah hukum-hukum yang bersifat universal (kulli) yang diikuti oleh satuan-satuan hukum juz'i yang banyak". ${ }^{25}$ Muh\}ammad Abu Zahrah menjelaskan bahwa kaedah fikih (alqawaid al-fiqhiyyah) adalah himpunan hukum-hukum syara' yang serupa (sejenis) lantaran ada titik persamaan, atau adanya ketetapan fikih yang merangkaikan kaidahkaidah tersebut. ${ }^{26}$ Lebih lanjut Muh\}ammad Abu Zahrah menjelaskan bahwa kaedah fikih (al-qawaid al-fiqhiyyah) adalah kaedah atau teori yang diambil dari atau menghimpun masalah-masalah fikih yang bermacam-macam sebagai hasil ijtihad para mujtahid. ${ }^{27}$ Menurut T.M. Hasbi Ash-Shiddieqy, kaedah-kaedah fikih (al-qawaid alfiqhiyyah) adalah prinsip-prinsip (mabda') dan dhabit-dhabit fikih yang masing-masing mengandung hukum yang umum. ${ }^{28}$ Sedangkan menurut Mukhtar Yahya dan Fatchur Rahman mendefiniskan kaedah-kaedah fikih (al-qawaid al-fiqhiyyah) sebagai kaedahkaedah umum yang meliputi seluruh cabang masalah-masalah fikih yang menjadi pedoman untuk menetapkan hukum setiap peristiwa fikih baik yang telah ditunjuk oleh nash maupun yang sama sekali belum ada nashnya. ${ }^{29}$

Dengan demikian kaedah fikih (al-qawaid al-fiqhiyyah) dapat diartikan sebagai himpunan kaedah-kaedah fikih yang umum yang meliputi seluruh cabang masalahmasalah fikih yang menjadi pedoman untuk menetapkan hukum setiap masalahmasalah fikih baik yang telah ditunjuk oleh nash maupun yang sama sekali belum ada nashnya. Setiap orang yang sanggup menguasai al-qawaid al-fiqhiyyah niscaya mampu

\footnotetext{
${ }^{23}$ Ahmad Warson Munawwir, al-Munawwir: Kamus Arab-Indonesia, Cet.XXV, (Surabaya : Pustaka Progressif, 2002), hal. 1138.

${ }^{24}$ Faturrahman Djamil, Filsafat Hukum Islam, (Jakarta : Logos Wacana Ilmu, 1999), hal. 76.

${ }^{25}$ Ah \}mad Muh \}ammad asy-Syafi‘i, Ushul al-Fiqh al-Islam, (Iskandariyah : Muassasah Tsaqofah alJami'iyyah, 1983), hal. 4, sama dengan yang ditulis oleh Beni Ahmad Saebani, Filsafat Hukum Islam (Bandung : Pustaka Setia, 2008), hal. 277.

${ }^{26}$ Muhammad Abu Zahrah, Ushul al-Fiqh, Terj. Saefullah Ma’shum, dkk., Cet. VI, (Jakarta : Pustaka Firdaus, 2000), hal. 7.

${ }^{27}$ Ibid. hal. 7.

${ }^{28}$ T.M. Hasbi Ash-Shiddieqy, Pengantar Hukum Islam, Jilid II, Cet.VI, (Jakarta : Bulan Bintang, 1981), hal. 101.

29 Yahya, Dasar, hal. 485.
} 
menguasai seluruh bagian masalah fikih dan sanggup menetapkan ketentuan hukum setiap peristiwa yang belum atau tidak ada nashnya.

\section{b. Macam-Macam al-Qawaid al-Fiqhiyyah}

Para ulama membagi kaedah fikih (al-qawaid al-fiqhiyyah) ke dalam dua bagian, yaitu:

1. Kaedah fikih induk/dasar (al-qawaid al-fiqhiyyah al-asasiah), yaitu prinsip-prinsip umum yang menjadi pedoman untuk menetapkan hukum dari setiap peristiwa fikih baik yang sudah maupun belum ada nashnya. Kaedah-kaedah ini disebut kaedah induk karena berpuluh-puluh kaedah fikih lainnya bernaung dan dapat dikembalikan kepadanya. Kaedah fikih induk ini ada lima dan disebut juga sebagai qawaid alkhams. ${ }^{30}$

2. Kaedah fikih yang bersifat umum (al-qawaid al-fiqhiyyah g\}airu asasiah), yaitu prinsip-prinsip yang bersifat umum yang karenanya dapat menampung seluruh bagian-bagiannya sampai yang terperinci sama sekali. Kaedah ini banyak sekali jumlahnya, sebagian ulama menetapkan sebanyak empat puluh kaidah dan sebagian yang lain menetapkan lebih dari itu. ${ }^{31}$

\section{c. Tujuan al-Qawaid al-Fiqhiyyah}

Tujuan al-qawaid al-fiqhiyyah adalah untuk memudahkan mujtahid dalam mengistinbat-kan hukum yang sesuai dengan tujuan syara' dan kemaslahatan manusia. Imam Abu Muhammad Izzuddin Ibnu 'Abbas Salam menyimpulkan bahwa kaidah fikih adalah sebagai suatu jalan untuk mendapat kemaslahatan dan menolak kerusakan serta bagaimana cara mensikapi kedua hal tersebut. ${ }^{32}$ Mukhtar Yahya dan Fatchur Rahman menyebutkan dua tujuan dari kaidah-kaidah fikih. Pertama, sebagai tempat kembali bagi para mujtahid dalam seluk-beluk masalah fikih, dan Kedua, sebagai dalil untuk menetapkan hukum masalah-masalah baru dalam fikih yang tidak ditunjuk oleh nash yang sharih. ${ }^{33}$

\section{d. Kedudukan al-Qawaid al-Fiqhiyyah}

Hal yang berhubungan dengan fikih sangat luas, mencakup berbagai hukum furu' Karena luasnya, maka itu perlu ada kristalisasi berupa kaedah-kaedah umum (kulli) yang berfungsi sebagai klasifikasi masalah-masalah furu' menjadi beberapa kelompok.

\footnotetext{
${ }^{30}$ Ibid, hal. 485.

${ }^{31}$ Ibid, hal. 485 .

${ }^{32}$ Asjmuni A. Rahman, Qoidah - Qoidah Fikih, (Jakarta : Bulan Bintang, 1976), hal. 17.

${ }^{33}$ Yahya, Dasar, hal. 485.
} 
Dan tiap-tiap kelompok itu merupakan kumpulan dari masalah-masalah yang serupa. Hal ini akan memudahkan para mujtahid dalam meng-istinbat-kan hukum bagi suatu masalah, yakni dengan menggolongkan masalah yang serupa dibawah lingkup satu kaedah.

Dalam pembahasannya, al-qawaid al-fiqhiyyah sering menggunakan sistematika atas dasar keabsahan kaedah, atas dasar abjad, atau berdasarkan sistematika fikih. Berdasarkan keabsahan kaedah, dibagi atas kaedah-kaedah asasiah dan kaidah-kaidah g\}airu asasiah. Jaih Mubarok membedakan kedudukan kaedah fikih menjadi dua, yaitu dalil pelengkap dan dalil mandiri. Yang dimaksud dengan dalil pelengkap adalah bahwa kaedah fikih digunakan sebagai dalil setelah menggunakan dua dalil pokok, yaitu Alquran dan sunnah. Sedangkan yang dimaksud dengan dalil mandiri adalah bahwa kaedah fikih digunakan sebagai dalil hukum yang berdiri sendiri, tanpa menggunakan dua dalil pokok. ${ }^{34}$

Atas dasar kenyataan itu, kedudukan kaedah fikih dalam konteks studi fikih adalah simpul penyederhana dari masalah-masalah fikih yang begitu banyak. Untuk itu, al-Syaikh Ahmad Ibn al-Syaikh Muhammad al-Zarqa' berpendapat "kalau saja tidak ada kaedah fikih ini, hukum fikih yang bersifat furu'iyyat akan tetap bercerai-berai" 35 Abd al-Wahab Khallaf dalam kitab Ushul Fiqh-nya ${ }^{36}$ berkata bahwa nash-nash tasyri telah mensyariatkan hukum terhadap berbagai macam undang-undang, baik mengenai perdata, pidana, ekonomi dan undang-undang dasar telah sempurna dengan adanya nash-nash yang menetapkan prinsip-prinsip umum dan aturan-aturan tasyri' yang kulli yang tidak terbatas terhadap suatu cabang undang-undang. Prinsip-prinsip umum dan aturan-aturan kulli tersebut memang dibuat sebagai petunjuk bagi mujtahid dalam menetapkan hukum dan menjadi pelita untuk mewujudkan keadilan dan kemaslahatan umat. Karena Alquran hanya menerangkan dasar-dasar yang menjadi sendi-sendi hukum itulah maka tampak keluasan dan elastisitas hukum Islam.

Ungkapan Khallaf tersebut mengisyaratkan bahwa lapangan fikih begitu luas, karena mencakup berbagai hukum furu', karena itu perlu adanya kristalisasi berupa kaedah-kaedah kulli yang berfungsi sebagai klasifikasi masalah-masalah furu' menjadi beberapa kelompok, dan tiap-tiap kelompok itu merupakan kumpulan dari masalah-

\footnotetext{
${ }^{34}$ Jaih Mubarok, Kaidah Fikih: Sejarah dan Kaidah Asasi, (Jakarta : RajaGrafindo Persada, 2002), hal. $29-40$.

${ }^{35}$ Ibid., hal. 40.

36 'Abdul Wahhab Khallaf, Ilmu Ushul al-Fiqh, Cet. XII, (Kuwait : Dar al-Qalam, 1987), hal. 197-199.
} 
masalah yang serupa. Dengan berpegang kepada kaedah-kaedah fikih (al-qawaid alfiqhiyyah), para mujtahid merasa lebih mudah dalam meng-istinbat-kan hukum bagi suatu masalah, yakni dengan menggolongkan masalah serupa di bawah lingkup satu kaidah. Banyak fuqaha' yang menyebutkan:

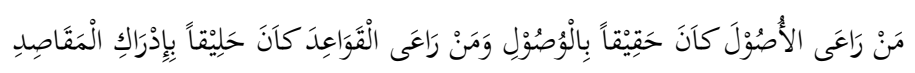

"barang siapa memelihara ushul, maka ia akan sampai pada maksud, dan barang siapa yang memelihara al-qawaid selayaknya ia mencapai maksud".37

Ungkapan tersebut menghantarkan kepada kepada kesimpulan bahwa kaedahkaedah itu menyingkapkan jalan-jalan yang ditempuh oleh para ahli fikih sehingga kita dapat mencontoh metode yang mereka tempuh. Andaikata kaedah-kaedah itu tidak ada, tentulah hukum-hukum fikih merupakan cabang-cabang yang berserak-serak tanpa ikatan dasar yang mengarahkan dan membuka jalan bagi usaha mengadakan perbandingan.

\section{Kedudukan Fikih, Ushul Fiqh dan al-Qawaid al-Fiqhiyyah dalam Pengembangan Ekonomi Syariah}

Sebagaimana yang telah dikemukakan pada pembahasan terdahulu, bahwa salah satu cabang dan objek kajian fikih adalah mengatur hubungan antara sesama manusia dalam rangka menegakkan hablun minannas, disamping mengatur hubungan dengan Allah Swt dalam rangka menegakkan hablun minallah. Kedua hubungan tersebut merupakan misi kehidupan manusia yang diciptakan sebagai khalifah di muka bumi. Hubungan dengan sesama manusia, seperti halnya dalam ekonomi akan bernilai ibadah bila dilaksanakan sesuai dengan petunjuk Allah Swt yang diuraikan dalam kitab fikih, khususnya fikih muamalah. Keberadaan fikih muamalah tidak bisa dilepaskan dari keberadaan ilmu ushul fiqh yang menjadi dasar atau pondasi bagi para ulama untuk menggali dan merumuskan hukum fikihnya.

Ekonomi Syariah dengan segala aktivitasnya merupakan bagian dari hubungan antara sesama manusia yang perlu mendapat pedoman serta petunjuk dari hukum syara', sehingga pelaku ekonomi syariah terhindar dari aktivitas yang dilarang oleh Allah Swt. Aktivitas ekonomi senantiasa mengalami perkembangan dan perubahan sesuai dengan kemajuan dalam kehidupan manusia. Oleh karena itu, aturan Allah Swt

\footnotetext{
${ }^{37}$ Rahman, Qoidah, hal. 17.
} 
yang terdapat dalam Alquran tidak mungkin mampu menjangkau seluruh aktivitas ekonomi yang terus berkembang, mengingat Alquran hanya memberikan pedoman sebagai garis-garis besar. Adapun aturan praktis yang lebih khusus datang melalui hadits Nabi Muhammad Saw. Namun jika masih terdapat hal-hal yang terkait dengan perkembangan aktivitas ekonomi dan belum secara jelas diatur dalam kedua hukum syarak tersebut (Alquran dan hadits), maka dapat disimpulkan oleh para ulama/faqih dengan menggunakan al-qawaid al-fiqhiyyah, sebagai tempat kembalinya bagi para mujtahid dalam seluk-beluk masalah fikih terkait dengan aktivitas ekonomi, dan sebagai dalil untuk menetapkan hukum dalam masalah-masalah ekonomi yang yang belum disimpulkan oleh nash yang sharih.

Dengan demikian, kedudukan fikih, ushul fiqh, dan al-qawaid al-fiqhiyyah tidak akan bisa dipisahkan dari aktivitas ekonomi syariah, terutama dalam menghadapi perkembangan ekonomi secara umum seperti saat ini. Bahkan ketiga disiplin ilmu tersebut merupakan landasan bagi terjadi aktivitas ekonomi syariah agar berjalan sesuai kehendak Allah Swt.

\section{Penutup}

Fikih merupakan seperangkat aturan hukum atau tata aturan yang menyangkut kegiatan manusia dalam berinteraksi, bertingkah laku dan bersikap yang bersifat lahiriah dan amaliah, yang merupakan hasil penalaran dan pemahaman yang mendalam terhadap syariah yang dilakukan oleh para mujtahid berdasarkan pada dalil-dalil yang terperinci. Fikih terbatas pada hukum-hukum yang bersifat aplikatif dan furu'iy (cabang) dan tidak membahas perkara-perkara i'tiqady (keyakinan) walaupun pada awal kemunculannya merupakan bagian yang tidak terpisah. Ushul fiqh adalah seperangkat pedoman, aturan-aturan atau kaedah-kaedah yang membatasi dan menjelaskan cara-cara yang harus diikuti oleh seorang mujtahid dalam upayanya menggali dan melahirkan hukum syara' dari dalil yang telah ada, baik dalam Alquran maupun sunnah. Sedangkan al-qawaid al-fiqhiyyah dapat diartikan sebagai himpunan kaedah-kaedah fikih yang umum yang meliputi seluruh cabang masalah-masalah fikih yang menjadi pedoman untuk menetapkan hukum setiap masalah-masalah fikih baik yang telah ditunjuk oleh nash maupun yang sama sekali belum ada nashnya. Fikih, ushul fiqh, dan al-qawaid al-fiqhiyyah tidak akan bisa dipisahkan dari aktivitas ekonomi syariah, terutama dalam menghadapi perkembangan ekonomi secara umum seperti 
saat ini. Bahkan ketiga disiplin ilmu tersebut merupakan landasan bagi terjadi aktivitas ekonomi syari'ah agar berjalan sesuai kehendak Allah SWT.

\section{Daftar Pustaka}

Ash-Shiddieqy, T.M. Hasbi. Pengantar Hukum Islam, Jilid II, Cet.VI. Jakarta: Bulan Bintang, 1981.

Djamil, Faturrahman. Filsafat Hukum Islam. Jakarta: Logos Wacana Ilmu, 1999.

Effendi, Satria dan M. Zaeni. Usul Fikih. Jakarta: Prenada Media, 2005.

Jumantoro, Totok dan Samsul Munir Amin. Kamus Ilmu Usul Fikih. Jakarta: Amzah, 2005.

Khallaf, Abdul Wahhab. Ilmu Usul Fikih, Cet. XII. Kuwait: Dar al-Qalam, 1987.

Mubarok, Jaih. Kaedah Fikih: Sejarah dan Kaidah Asasi. Jakarta: RajaGrafindo Persada, 2002.

Munawwir, Ahmad Warson. al-Munawwir: Kamus Arab-Indonesia. Cet.XXV. Surabaya: Pustaka Progressif, 2002.

Rahman, Asjmuni A. Qoidah-Qoidah Fikih. Jakarta: Bulan Bintang, 1976.

Saebani, Beni Ahmad. Filsafat Hukum Islam. Bandung: Pustaka Setia, 2008.

Syafe'i, Rachmat. Fikih Mu'amalat. Bandung: Pustaka Setia, 2004. . Ilmu Usul Fikih. Bandung: Pustaka Setia, 2007.

asy-Syafi'i, Ahmad Muhammad. Ushul al-Fiqh al-Islam. Iskandariyah: Muassasah Tsaqofah al-Jami'iyyah, 1983.

Syarifuddin, Amir. Garis-Garis Besar Fikih. Jakarta: Prenada Media, 2003. . Ushul Fiqh Jilid 1. Jakarta: PT. Logos Wacana Ilmu, 1997.

Wuzarah al-Awqaf wa asy-Syun al-Islamiyyah. al-Mausu'ah al-Fiqhiyyah. Kuwait: Wuzarah al-Awqaf wa asy-Syu'un al-Islamiyyah, Cet. 2, 1983 M/1404 H.

Yahya, Mukhtar dan Fatchur Rahman. Dasar-Dasar Pembinaan Fikih Islam. Bandung: Alma'arif, 1986.

Zahrah, Muh\}ammad Abu. Ushul al-Fiqh, Terj. Saefullah Ma'shum, dkk., Cet. VI. Jakarta: Pustaka Firdaus, 2000. 